\section{New Foreign Members of the Linnean Society}

THE four recently elected foreign members of the Linnean Society are all botanists. Dr. A. F. Blakeslee, assistant director in the Department of Genetics at the Carnegie Institution of Washington, is not only an outstanding geneticist but was also the discoverer of the phenomenon of heterothallism in the Mucorineæ, which has had a most profound influence both on the study of fungi and on theories of sex. Prof. P. A. Dangeard, until lately professor of botany at the Sorbonne, is known chiefly as a mycologist and cytologist though he has covered a very wide field in botanical research: he has been responsible for Le Botaniste since 1889, contributing the whole of many of the volumes. Prof. G. Senn, director of the Botanical Institute at Basle, is a botanist of many-sided activities. At first mainly interested in algal flagellates, he turned his attention to the physiology of the plant cell, studying particularly the chromatophore. More recently he has written a valuable treatise on the botany of Theophrastus. He has also worked on alpine plants. Prof. C. Raunkiaer, formerly professor of botany at Copenhagen, has considerably influenced ecological thought by his work on growth forms. He has been chiefly interested in phytogeography, morphology, taxonomy and statistical methods. His papers have recently been translated into English under the title "The Life Forms of Plants and Statistical Plant Geography".

\section{Dr. Herbert Smith}

The Principal Trustees of the British Museum have appointed Dr. George Frederick Herbert Smith to be keeper of mineralogy in the British Museum (Natural History), in succession to Dr. L. J. Spencer, who retires on July 7 next. Dr. Herbert Smith was born in 1872. He was educated at Winchester, and at New College, Oxford, where he held a Winchester scholarship. He took a first in Mathematical Moderations (1892), Final School of Mathematics (1895) and Natural Science School, Physics (1896). He entered the Museum as an assistant in the Department of Mineralogy in 1897, and soon became recognised as an authority on mineralogy and crystallography, and wrote numerous papers on these subjects. His book on gem-stones has for many years been used as the standard textbook in the jewellery trade. $\mathrm{He}$ invented the three-circle goniometer, and a handrefractometer for the determination of gem-stones. Dr. Herbert Smith's interest in general civil service problems led to his appointment in 1921 to the post of secretary of the Museum, which he has since held. $\mathrm{He}$ is honorary secretary of the Society for the Promotion of Nature Reserves, and chairman of the Wild Plant Conservation Board.

\section{Franklin Institute Medals Awards}

SCIEnCE SERvice of Washington, D.C., states that the Franklin Institute, Philadelphia, has recently awarded Franklin Medals to Prof. Albert Einstein for his researches on relativity and the photo-electric effect, and to Sir Ambrose Fleming for his work on the thermionic valve. A certificate of merit has been awarded to G. S. Kelley, of New York, for reducing rock dust hazard. The following medal awards have also been made for the work indicated: Edward Longstreth Medals to Edmund Bruce of the Bell Telephone Laboratories (short wave radio antennæ) ; Howard D. Colman and B. A. Petersen of Rockford (an automatic spooler); P. Davey of New York (a portable balancing device); and K. B. MeEachron of the General Electric Co., Pittsfield (for developing the material thyrite): John Price Wetherill Medals to Dr. F. F. Lucas of the Bell Telephone Laboratories (photomicroscopy); R. E. Naumburg of New York (an unusual mechanical apparatus); W. H. Shortt and F. Hope-Jones (precision clocks); Dr. J. E. Shrader of Drexel Institute, Philadelphia (a vibrationmeasuring instrument); Dr. L. B. Tuckerman of the National Bureau of Standards (an optical strain gauge); H. E. Warren of Ashland, Mass. (the telechron used in electric clocks): Walton Clark Gas Medal to F. J. West of Manchester (work in the gas industry): Louis Edward Levy Medal to Dr. H. L. Hazen of the Massachusetts Institute of Technology (mechanical robots or servo-mechanisms).

\section{The Quetta Earthquake of May 3I}

WrrHIN little more than sixteen months, the Indian Empire has been visited by another great destructive earthquake. On May 31, at about 2.45 a.m. (probably about 9.15 p.m. on May 30 , G.M.T.), the cities of Quetta, Mastung and Kalat were almost entirely razed to the ground. In Quetta alone, the loss of life is estimated at more than 20,000. The region is one that has frequently been disturbed by destructive earthquakes. The valuable report by $\mathrm{Mr}$. W. D. West on those of August 25 and 27, 1931, has recently been noticed in Nature (April 27, p. 661). The earlier shock had its centre near Sharigh, which lies 39 miles east of Quetta; the later and stronger near Mach, 26 miles south-east of the same city. In the recent earthquake, the epicentral area-if we may take it as lying along the Quetta-Mastung-Kalat line-is roughly parallel to the zone joining Sharigh to the main part of the Mach area, and about 50 miles to the west. It is also parallel to the main structural lines of the country, and especially to the great boundary fault, 45 miles to the west, that runs along the west side of the Khojak Range for a distance of at least 120 miles. It was to a nearly horizontal shift of about $2 \frac{1}{4} \mathrm{ft}$. along this fault that the severe earthquake of December 20, 1892, was due.

\section{Revision of Ordnance Survey Maps}

WE are glad to note that the Minister of Agriculture has appointed a committee, under the chairmanship of Mr. J. C. C. Davidson, Chancellor of the Duchy of Lancaster, to consider the measures necessary to accelerate the revision of the Ordnance Survey maps. The maps in question are the large-scale plans, that is, the 25-in., the 6-in. and, in some cases, even those on larger scales, but chiefly those 
mentioned. The small-scale maps, namely, those on the 1 -in. and smaller scales, present no problem. The large-scale plans, which are numbered by tens of thousands, have been gradually getting very much out of date. This is mainly due to two causes : the action of the Geddes Committee of 1922 in recommending further reductions in an already reduced department, and the great alteration in the countryside caused by the expansion of the built-up area and the spread of 'ribbon development'. There is also the further difficulty that, simultaneously with the enforced slowing up of revision, there has been an increased demand for the large-scale plans for town planning and for land registration. It is clearly high time that the whole matter was examined. Many interests are involved, as is indicated by the fact that no fewer than six public departments are represented on the Committee. The question is somewhat urgent, and it is to be hoped that the Committee may be able to report speedily, for every month the arrears become more serious. There is one curious item in the terms of reference; the Committee is to "review the scales and styles of Ordnance Survey maps placed on sale". It is not to be desired that we should enter again upon the 'battle of the scales' which was happily decided more than two generations ago. Nothing has happened since then to throw doubt upon the wisdom of the choice of the 25 -in. scale as that of our principal large-scale plans. That old 'battle of the scales' lasted from 1840 until 1863, and since the latter date the country has enjoyed, in this matter, the great advantage of an uninterrupted, continuous policy.

\section{Civil Aircraft in the Royal Air Force}

THE Air Ministry has acquired a De Havilland Dragon Rapide and an Avro Ava, two well-known commercial types of aircraft, for R.A.F. use. Such purchases indieate two possible lines of attack on the problem of rapid expansion recently announced. The degree of military usefulness of such machines, and the amount of modification necessary, can be studied in actual experiment by the R.A.F. personnel concerned. Also the more immediate problem of obtaining a sufficient supply of machines for training and flying practice, for the increased establishment under the new R.A.F. expansion scheme, will be helped, if civil machines are found suitable, and can be built immediately in factories already in produc. tion of them. It is understood that the first two of the five new training schools are to be opened this month, each school having the equivalent of three squadrons. Thus the problem of equipment is not only to supply these, but also a progressively increasing number of machines for the use of these pupils as they pass out into the service. It has to be discovered whether it is best to allow constructing firms to accelerate the production of their own aircraft, modified to R.A.F. requirements, or to change them over to contracts to build other machines specifically designed for R.A.F. work. Large contracts have also been placed for the construction of aeroplane hangars in various places.

\section{German Commercial Airship Plans}

The new Zeppelin, Airship L.Z. 129, is now reported to be complete in skeleton, and work on covering has commenced. It is hoped to launch it at the end of July. When completed it will be the largest airship in the world. It is $813 \mathrm{ft}$. in length, $135 \mathrm{ft}$. maximum diameter, and has gas capacity of 6,720,000 cubic feet. Dr. Eckener says that he intends to build three further ships for routes across the North Atlantic, South Atlantic, and to India and Batavia, that will operate under American, German and Dutch control respectively. The German operating base will be changed from Friedrichshafen to Frankfort, which is not only more convenient for commercial traffic but is also at a lower altitude. The loss of available lift due to starting from the higher altitude of Friedrichshafen is estimated to be about three tons for the L.Z. 129. Arrangements have also been completed for the construction of a mooring mast and gas plant at Seville, in conjunction with the Atlantic routes. A new operating company, in which the German Government is said to be interested, is being formed with a capital of about $£ 835,000$.

\section{The Admiralty Magnetic Survey Ship}

AT the sixteenth annual meeting of the American Geophysical Union, held at Washington on April 26, the following resolution was adopted: "WHEREAS, The magnetic survey of the oceanic areas, carried on for 25 years by the Carnegie Institution of Wash. ington, was brought to a sudden end by the destruction of the Carnegie at Apia, Western Samoa, November 29, 1929, in the course of a cruise designed to determine the secular change of the Earth's magnetism in all oceans, and WhErEAs, It is of very great importance, not only for the practical needs of the navigator but also for the effective study of the Earth's magnetism, that these observations be resumed at an early day, and Whereas, It has been announced that the British Admiralty has decided to build a non-magnetic vessel, designed primarily for securing magnetic data at sea, therefore be it Resolved, That the American Geophysical Union is highly gratified at this action of the British Government, assuring, as it does, the continuance of the ocean magnetic work, and expresses the hope that the construction and equipment of the vessel may be pushed to a speedy conclusion, and be it further Resolved, That a copy of this resolution be sent to the British Admiralty, to the Astronomer Royal, and to the Chairman of the British National Committee for Geodesy and Geophysies." In transmitting this resolution, Dr. Isaiah Bowman, chair. man of the National Research Council, writes, "All geophysicists must extend grateful thanks to the British Admiralty in making possible the further accumulation of data so essential to the needs of navigators and of scientific enquiry".

\section{Noise Abatement Exhibition at the Science Museum}

ON May 31, the Prime Minister opened the Noise Abatement Exhibition which has been organised by 